\title{
Implementation of Institution's E-Learning Platform in Teaching Online at ITB AAS Indonesia
}

\author{
Tira Nur Fitria \\ Institut Teknologi Bisnis AAS Indonesia \\ tiranurfitria@gmail.com
}

\begin{tabular}{ll}
\hline Article History & Received : January $7^{\text {th }} 2021$ \\
& Revision : February $11^{\text {th }} 2021$ \\
& Publication : March 30 3021 \\
\hline
\end{tabular}

\begin{abstract}
E-learning is one of impact of the development of information and communication technology (ICT) technology applied in education using the accessible website. The purpose of this research is to know the implementation of the Institution's E-Learning Platform and to know the strengths and weaknesses of the implementation of the Institution's E-Learning Platform of ITB AAS Indonesia. This research applies descriptive qualitative research. The result of the study shows that ITB AAS Indonesia began implementing e-learning to support face-to-face classrooms in the academic year 2020/2021. E-learning's platform was made based on Learning Management System (LMS) that can be accessed at the website https://elearning.itbaas.ac.id/ Based on the implementation of the e-learning, there are several menus found such as "Home, Message, Teaching Schedule, Material, Task, My Comment, Lecturer's Filter, Student's Filter, Video Conference, and Logout". But, during the observation of the implementation of the e-learning platform, there are several strengths and weaknesses. In strengths are 1) Multi Users, 2) Online Application. 3) Several menus available. In the weaknesses, 1 . This application contains a lot of data, 2. This application's design will only look good when opened by using a laptop or a computer, 3. In making the material, it can only be shared into the Study Program category- Semester, and it cannot be shared with each class. 4. There may be the possibility of sending the material incorrectly. 5. This application does not have the facilities for importing and exporting user data. 6. In making multiple-choice question assignments, there is still a manual import feature, 7. E-learning does not have a Video Conference feature, 8. In printing grades into a file $p d f$, an additional application is required. 9. E-learning cannot record learning and participants in a video. 10. This application does not have an installer version on the android/smartphone.
\end{abstract}

Keywords: E-learning, E-learning's platform, teaching online

\section{Introduction}

The increasing development of IT programs has had a profound influence on university teaching and learning. (Mohmedsali et al., 2017). In today's digital age, it seems as if all activities in life can be carried out remotely as well as the educational aspect. Solangi et al. (2018) state that the concept of teaching and learning through the use of media internet, such as social media networks, and android/smartphone apps has rendered simpler and casual for both students and teachers. 
In almost every topic, the use of the internet can be powerful in teaching (Gluchmanova, 2015). According to (Crane, 2016), technology also plays an important role in online learning. Garrison (2011) E-learning claims that ad electronically facilitated asynchronous and synchronous correspondence for the creation and conformity of information is formally described. The Internet, which is related to networking technology, is the technical base of e-learning. The internet has facilitated E-learning (Fitria, 2020). E-learning is converted through the Internet from existing structures of traditional educational facilities into a digital structure. (Aulia, 2017).

E-learning aims to provide a structure for interpreting the application of elearning in higher education in the 21st century. (Garrison, 2011). E-learning is applied to a modern framework through the internet from existing systems of traditional educational institutions. E-learning, by network technology, is online facilitated learning. This does not relate to technologies or approaches, but it includes components of face-to-face educational experiences.

Electronic learning (e-learning) is gaining a foothold in education worldwide (Gunasekaran et al., 2002). E-learning refers to the learning in which the learner and the teacher are separated by time or space where electronic tools are used to close the gap between the two (Umadevi et al., 2014). E-learning provides a unique opportunity (Bian, 2009). As Iskander (2007, p. 420) states that It is important to build an e-learning platform that enables users' access to learning materials. The benefits made from this elearning application program are as follows: 1 . Assisting the campus in managing the learning process for the current conditions of the Coronavirus pandemic. 2. Assisting lecturers in conducting the lecture process which can be done remotely online and in an LMS system. 3. Helping campus students in the online distance lecture process and an LMS system. 4. Prospering campus education in the current pandemic condition, because lecture learning is still active online.

Yefim (2010, p. 21) states that with the existence of the internet, Web and the institutionalization of e-learning, web-based e-learning systems are built to include all facets of a single, cohesive user experience. Various open-source and commercial elearning platforms are available to practitioners, developers, and users (Claus, 2007, p. 118). As supported by (Fee, 2009, p. 77), in an e-learning context, we have learned any platforms such as LMS or CMS. E-learning platforms that can be used to provide students with online learning, such as the Learning Management System (LMS), the Learning Content Management System (LCMS), the Learning Design System (LDS) and the Learning Support System (LSS), both of which can be a bridge for teachers.

Learning Management System (LMS) is system of an e-Learning that is more widely used by institutions around the world. If defined simply, e-Learning systems are designed to manage, distribute, plan and evaluate a specific learning process. This system can be in the form of a website-based system or one based on applications on smartphones or hybrids (web and application-based). For example, Google Classroom, Edmodo, Moodle, Schoology, EdLink, or the institution's platform. They often offer quite similar functions such as in support for collaborative work, but they still differ. Usually, the role of e-learning sites includes access to learning material and assessments, learners' networking and collaboration resources, course management, and instructors' evaluation facilities. Administrative tasks or processes can also be used on the networks. The popularity of the E-learning platform then grew rapidly due to its 
flexible use and rapid development of information technology (Nurseha \& Pradany, 2014).

Tsai et al. (2017) define that an e-learning system is to review homework responses and upload assignments was used as a support program for the students. Besides, after a mid-term review, an assignment was circulated to allow the undergraduates to practice outside the classroom with online learning materials. Therefore, during learning, the online training portal can have a welcoming tool and target the theoretical values and desires of users. Yefim $(2010$, p. 31$)$ states that the in an educational framework, the e-learning framework offers comprehensive support for the six tasks, such as development, organisation, distribution, connectivity, coordination and assessment. The word 'integrated' here suggests that, regardless of the real implementation. An e-learning platform must function as one mechanism and as a single system must be conveyed to users.

A standard learning management system has content delivery facilities, e-mail, tasks/exercises, mailing lists, forums, tests, self-assessment, group work, talk, calendar, surveys, FAQs, wikis, journals, glossaries, video conferencing, journal, whiteboard, learning routes, podcast, student portfolio, student monitoring, and podcasting (Banday et al., 2014). According to Munkhtsetseg \& Uyanga (2013), building the online learning infrastructure also needs consideration of several factors. The infrastructure model of the e-learning system consists of interconnected elements, such as the e-learning system, the information system of university management, the e-library system, the creation of e-content, and other services for students.

Some limitations related to E-learning as stated by Sarker et al. (2019) in their research as the learning materials are poorly structured and do not allow for many contacts between teachers and students. Several technical issues hinder access to elearning sites such as poor internet connectivity. According to Billings (2002, p. 5), there are disadvantages related to e-learning. The educators and learners must consider it when making decisions about teaching and learning. One of them has to do with the technology including how and why to access it, the reliability of the infrastructure, and the difficulty in a face-to-face atmosphere like a realistic lesson, e-learning

models are used to teach content that is best learned. As stated by Haythornthwaite \& Andrews (2011) that e-learning involves a multi-faceted phenomenon that comprises social and technical dimensions.

Online teaching which uses e-learning has begun to be carried out in many institutions/universities in Indonesia. However, the implementation of online teaching can be different. Several educational institutions such as colleges/universities have now provided e-learning system services that make it possible for students to attend lectures over long distances. This can be realized thanks to the Ministry of Education and Culture Regulation Number 24 of 2012, which regulates distance education. With this system, learning activities can take advantage of the latest information, communication, and media technology, especially digital. As the name implies, the concept of online teaching is teaching that is carried out online and is supported by information technology. If conventional teaching applies face-to-face teaching and learning activities at campus, then online teaching applies an e-learning system, aka learning activities using internet media. In the classroom, technology offers us much more than blackboards and chalk ever did. (Blackburn, 2017). 
One of the universities that have started to implement an e-learning system based on Learning Management System (LMS) Institute of Business Technology (ITB) AAS Indonesia, Surakarta Central Java which can be accessed at https://elearning.itbaas.ac.id/. There is provided lecture material, assignments, and even online discussions can also be done in the e-learning system. This E-learning was established to bridge distances, time, and various conditions that can hinder learning activities. Not only that, but e-learning is also here to optimize the use of technology to maximize learning outcomes.

Some previous studies also related to this research as references for the researcher. The first is written by Mohmedsali et al. (2017) entitled "Investigating Factors Influencing the Implementation of e-learning at Rural Based Universities". This research aims to examine the factors affecting the introduction of LMS for both students and lecturers. The second research is written by Solangi et al. (2018) entitled "Factors affecting Successful Implementation of eLearning in RCJ Saudi Arabia". This study aims to examine the different factors that influence the successful implementation of elearning. The third research is written by Sarker et al. (2019) entitled "Use of e-learning at higher educational institutions in Bangladesh: Opportunities and challenges. This study aims to examine the suitability of the introduction of successful e-learning at tertiary education institutions in Bangladesh through LMS, and how the learning platform is experienced and responded to by both students and teachers. The fourth research is written by Banday et al. (2014) entitled "Applications of e-Learning in engineering education". This study to find the uses of e-learning in engineering education and its actual implementation. The fifth research is written by Gluchmanova (2015) entitled "Application of e-learning in foreign language teaching at the technical university". The sixth research is written by Munkhtsetseg \& Uyanga (2013) entitled "Implementation of E-Learning System". This study describes the implementation of the e-learning system at the School of Mathematics and Computer Science, National University of Mongolia. The seventh research is written by Idris \& Osman (2016) entitled "Implementation of E-learning in The University of Gezira Barriers and Opportunities". The study aims to assess the factors affecting the adoption of e-learning at Gezira University and proposed possible solutions to the challenges. Related to all previous studies above, there is similarity between those previous studies with this research. In similarity, all previous studies also focus on e-learning implementation. But, in differences, all previous study has the object outside of Indonesia, then this research focuses on e-learning in Indonesia.

Based on the explanation above, here the researcher is interested to conduct a study about e-learning implementation. Therefore, the purpose of writing this research is to know the implementation of the Institution's E-Learning Platform of ITB AAS Indonesia and to know the strengths and weaknesses of the implementation of the Institution's E-Learning Platform of ITB AAS Indonesia.

\section{Research Method}

This research applies qualitative research. The process in qualitative research is inductive. It is different from quantitative which is deductively deriving hypotheses to be tested (Merriam \& Grenier, 2019, p. 6). Here, the researcher gathers data to build concepts or theories in understanding the meaning of the phenomenon involved. 
In this research, the technique of collecting data uses observation. Merriam (2009, p. 119) states that observation is one of the techniques to be used when it is first possible to observe an action, case, or circumstance, when a new insight is needed, or when participants are not able or ready to address the subject under review. In qualitative research, an observer can play several roles, including participating in what they want to observe (Rubin \& Babbie, 2009, p. 226). But, in this research, the researcher observes the lecturer in implementing teaching online by using E-learning's platform based on Learning Management System (LMS) in Institute of Business Technology (ITB) AAS Indonesia which can be accessed at the website https://elearning.itbaas.ac.id/.

In this research, a technique of analyzing data uses three-step analysis as proposed by Miles \& Huberman (1994) in Silverman (2009, p. 234), they are 1) Reduction of data (refers to the collection, concentrating, abstraction, and transformation phase of raw data. 2) Display of data (refers to showing data in displays such as matrics, graphs, statistics, photographs, etc. 3) Conclusion (refers to deciding the result data descriptively).

\section{Findings and Discussion}

\section{Findings}

Implementation of Institution's E-Learning Platform

Some steps in implementing the e-Learning platform of ITB AAS Indonesia. First, the lecturers click on the official website of e-Learning ITB AAS Indonesia at the website https://elearning.itbaas.ac.id/ so that it appears as follows:

Figure 1. Official website of e-Learning

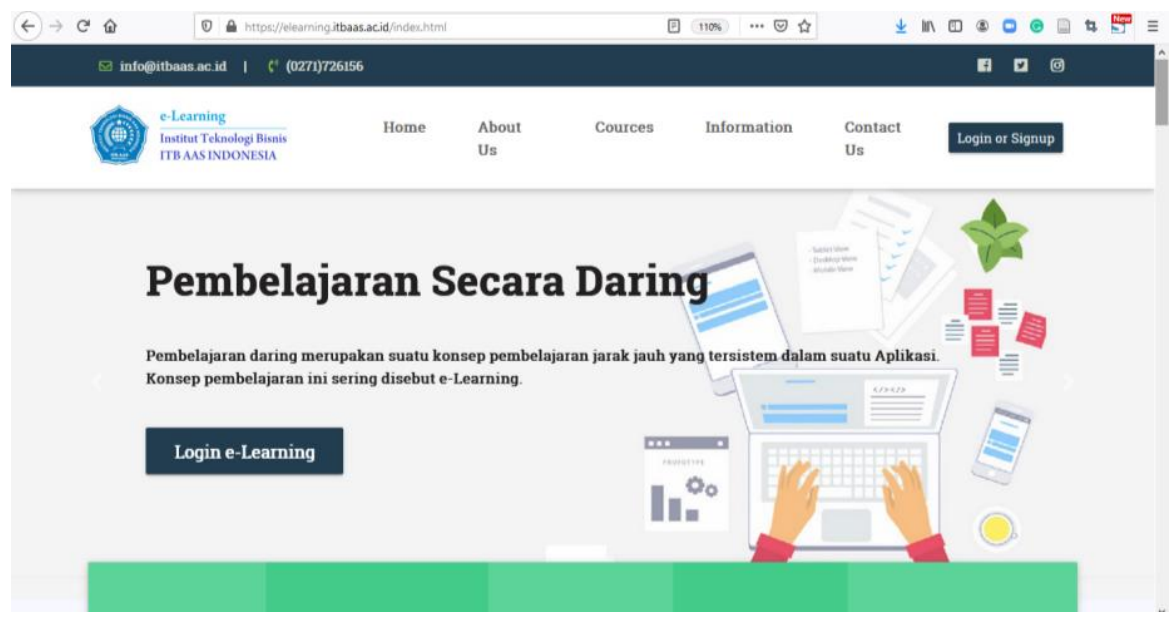

Second, the lecturers click "Login e-Learning". To be able to log in, the lecturer can use the Username and Password provided by the campus, so that it will appear as follows.

Figure 2. Login E-learning 


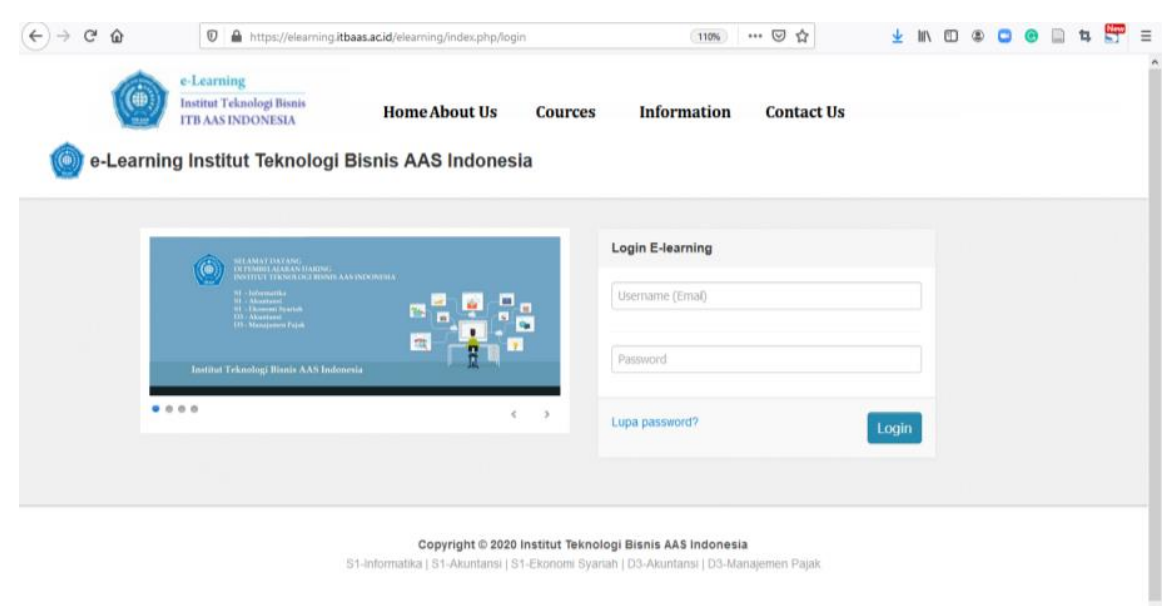

Third, after logging in, the preview of e-learning will be seen as follow:

Figure 3. Login E-learning

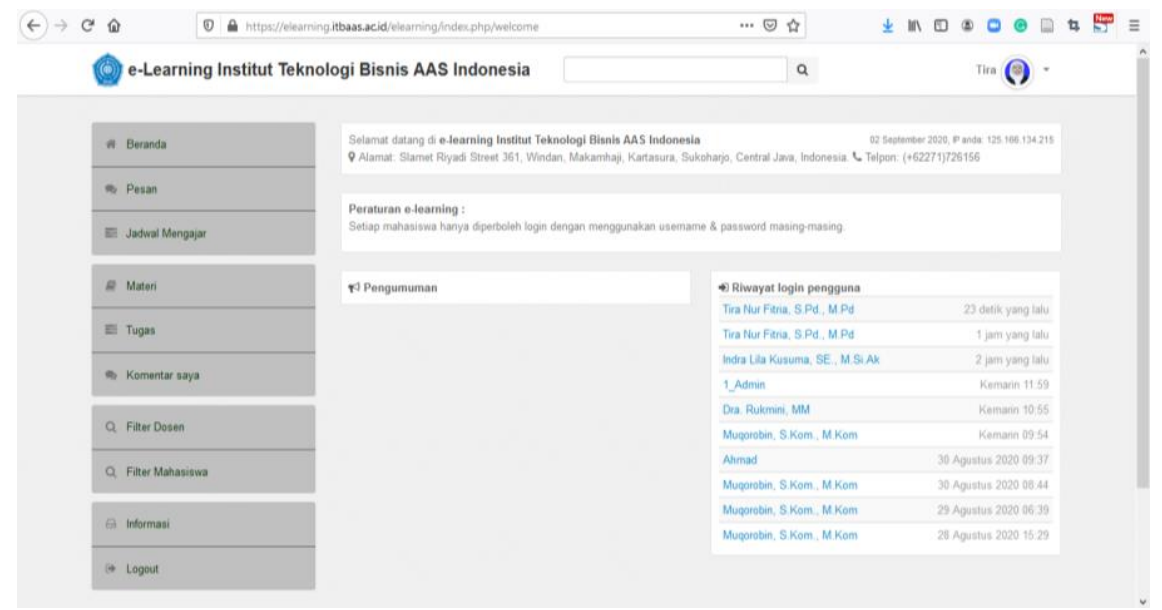

Based on the figure above, shows that there are several menus on the screen such as "Home, Message, Teaching Schedule, Material, Task, My Comment, Lecturer's Filter, Student's Filter, Video Conference, and Logout".

a. Home. This menu functions as the main page of the e-Learning application. The lecturer can click the Home menu. There is information on the "Institution Address", "Announcements" from the campus (filled in by admin), and "History List", namely the history of the time the user logs into the application (it will automatically record) this can be used as lecturer attendance in monitoring students' activity.

b. Message. This menu function is to create messages, discussions of all users, both lecturers and students. If the lecturer wants to send a message, he/she can click "Write Message", then in the recipient column, type the name of the recipient (lecturer or student). After that, click on the message, then the students can also reply to the message that has been sent.

c. Teaching Schedule. This menu function is to create lecture schedules (this schedule can be made by the campus admin or the lecturers (according to campus policy). Lecturers can add to the schedule on Monday even though there are different classes, the schedule will automatically appear in each class. 
d. Material. This menu function is to make the material in writing and files. In 'Written material', this menu function is to provide article material (text, image, video, link) which will appear on the students' page such as posting a website/blog article. To create written material, the lecturer can click the "Material Menu", then "Add Written Material". After that, there are a few buttons such as "Preview", "Save Only", "Save \& Publish" and "Back". The menu "Preview button" is to see the results of the temporary content display. The menu "Save Only" button is to save only material without publishing it on the student page. The menu "Save \& Publish" button is to save as well as display student pages. While the menu "Back" button is to cancel the material. If the lecturer wants to see the material temporarily, he/she can click the "Preview" button. In 'Material File', this menu function is to provide module material in the form of files, such as Word, Pdf, Excel, Jpg, etc. In uploading the file material, the lecturer can click the "Material" menu, click "Add Material File", enter the "Title", "Select Subject", "Class", then "Choose File". If the lecturer wants to publish immediately on the students' page, he/she can click "Save \& Publish". "In Status" will appear: "Published" then click the "Update" button.

e. Tasks. This menu function is to give the tasks to students. There are 3 types of assignments in this application, namely "Add Multiple Tasks", Add Essay Task" and "Add to Upload Tasks". Multiple assignments are assignments in the form of multiple-choice questions. The questions can be made by the lecturers within a time limit and the results of the scores can be directly calculated on the total value, they can also be exported to Excel and print. While essay assignments are assignments in the form of written essays. The lecturer can make essay questions while the students can answer the essay questions within a time limit. For the assessment, it can be seen that the answers from students and the lecturer directly, then the final results can be exported to Excel and print. Upload assignments are assignments given by the lecturer to students. The students can upload document files so that the lecturers can correct students' work results.

f. My Comments. This menu functions to see the overall comments from the students to the teacher on each material. The lecturer can click the "Material" menu. After that, click details, then the material will appear. The lecturer can comment on the material that he/she has sent to the students. After that, click "Post Comments".

g. Lecturer Filter. This menu functions to find the lecturer's file. On the "Lecturer Filter" page, it is useful to sort lecturers' names or search for lecturers' data. After being found, the students can see the complete lecturer data and can give comments or fast to the lecturer.

h. Student Filter. This menu functions to find the students' files. On the "Student Filter" page, it is useful for sorting students' names or searching for students' data. After being found, the lecturer can see the complete students' data and can give comments to students directly and quickly.

i. Information. This menu function is to find tutorial information on how to do a video conference with Google Meet. For an explanation, the lecturer can click the "Video Conferences" menu. There are several choices of "Instructions for Lecturers", "Presentations" and "Instructions for Students". The lecturer can click the option for "Instructions for Lecturers" then the lecturer can click the option 
"Start Presentation". To be able to use Video Conference, the lecturer must have a Gmail account or log in to Gmail first.

j. Logout. This menu functions to exit the e-learning application program. When the lecturer has finished using this e-learning application, then he/she can close this application by clicking the "Logout" menu.

\section{Strengths and weaknesses during the Implementation of Institution's E-Learning Platform}

E-learning refers to the use of information and communication technology for access to online tools for learning/teaching. (Arkorful \& Abaidoo, 2014). E-learning as a form of information technology applied in education is an accessible website. During the observation of the implementation of the e-learning platform, there are several strengths and weaknesses. In strengths are: 1) Multi Users. This application can be accessed by Admins, Lecturers, and Students. 2) Online Application. This application can be accessed via Laptops, Computers, and Gadget/Smartphones which connected to the internet. 3) There are several menus such as Information System includes Campus Information, Study Program, Semester, Class, Course material content (Lecturer's Summary), Announcement Menu (to inform all students and lecturers), Message Menu (introductory discussion users (lecturers and students), Teaching Schedule Menu (class menu), Material menu, Menu Assignments, Comment Menu, Lecturer filter, Student Filter, Video Conferences menu (by using Google Meet), Log in, Export the value of the assignment, Print the report on the value of the task, multi-course (more than 100 courses) and user login security feature, where each user can only log in once at a time so that each user cannot log in anywhere.

While the weaknesses of the implementation of the e-learning platform are as follows: 1 . This application contains a lot of data, so there is a big possibility that it will take a long time to open or access the e-learning website. 2. This application's design will only look good when opened using a laptop or a computer, if we open it by using a cellphone or smartphone, the appearance will break for the solution. We must set the desktop mode from the cellphone. 3. In making the material, it can only be shared into the Study Program category - Semester, and cannot be shared with each class. 4. Lecturers are given access rights to share materials in various subjects and classes. There may be the possibility of sending the material incorrectly. 5. This application does not have the facilities for importing and exporting user data. 6. In making multiple choice question assignments, there is still a manual import feature for multiple-choice assignments and essays. 7. There is no Video Conference feature, but there is a tutorial on how to do a video conference by using Google Meet. 8. In printing grades into file .pdf, an additional application is required. 9. There are no learning record participants. 10 . This application does not have an installer version on the android/smartphone.

\section{Discussion}

E-learning ITB AAS Indonesia is a project that is being developed by the ITB AAS Indonesia ITB Informatics Lecturer Team. This application is based on LMS (Learning Management System), the learning process can be managed or managed by a system based on learning standards. This application has 3 user access rights, namely admin, teacher/lecturer, and student/student. Each access right has different menu capabilities 
or facilities. For admin access rights, the role of managing the application system as a whole can even manage teacher/lecturer and student/student data.

This e-learning application program is a useful medium for distance learning (online lectures). This media was created because it is an alternative to learning during the current coronavirus pandemic. ITB AAS Indonesia campus has taken one good breakthrough so that the learning system continues to run well, a special e-learning application is made for students. This application can be accessed online via smartphones and computers. To get good display results, then access this application using a computer. Meanwhile the teacher/lecturer access rights play a role in providing material, assignments, and discussions/messages with students. Meanwhile, students/students can only receive information, material, tasks/assignments, and discussions/messages from the teacher/lecturer. This application can check active and passive students during online lectures. Besides this application can also provide announcements or information that can be accepted by all students, students. This application can control learning based on the syllabus and RPS so that the lecture learning program can run according to lecture standards.

The objectives of making the program from this e-learning application are as follows: 1 . This application is made as a medium for learning online distance lectures that provide easy learning for lecturers and students. 2. This application is based on LMS (Learning Management System) where all learning concepts can be controlled according to the lecturer learning system referring to the Syllabus and RPS (Rencana Pembelajaran Semester). 3. E-learning applications can be made to help distance lectures that will be applied at the beginning of the academic year 2020/2021.

E-learning ITB AAS Indonesia began implementing online teaching to support faceto-face classes. So, technology and online learning concepts are utilized to improve teaching quality. This e-learning platform can be accessed at https://elearning.itbaas.ac.id/. There is provided lecture material, assignments, and even online discussions can also be done in the e-learning system. This E-learning was established to bridge distances, time, and various conditions that can hinder learning activities. E-learning is applied to a modern framework through the internet from existing systems of traditional educational institutions. A teacher will provide materials to students who are in various places connected by the internet. This method is more or less the same as the teaching and learning process in a conventional class. But, still are found several strengths and weaknesses in the implementation of the Institution's elearning platform.

\section{Conclusion}

The implementation of online learning or online teaching requires readiness for both parties, namely from educational service providers, teachers/lecturers, or the students themselves. Because after all, online and distance learning requires qualified technical assistance and can be accessed easily by all those concerned in it. It cannot be done when the student is ready but the supporting media is not adequate. Besides that, students or students are also required to prepare themselves to adapt to learning changes regulated by schools and universities. In e-learning learning like now, teachers or lecturers will be challenged to be even more creative. This is because teachers or lecturers can mix various media including text, video, audio, infographics, presentation 
slides, games, and other media which are proven to be more effective than content or learning material which is only text or audio.

\section{References}

Arkorful, V., \& Abaidoo, N. (2014). The role of e-learning, the advantages and disadvantages of its adoption in Higher Education. International Journal of Education and Research, 2(12), 397-410.

Aulia, R. (2017). Analisis E-Learning Sebagai Media Bantuan Pengajaran di Lingkungan Kampus [Preprint]. INA-Rxiv. https://doi.org/10.31227/osf.io/gjvh4

Banday, M. T., Ahmed, M., \& Jan, T. R. (2014). Applications of e-Learning in Engineering Education: A Case Study. Procedia - Social and Behavioral Sciences, 123, 406-413. https://doi.org/10.1016/j.sbspro.2014.01.1439

Bian, L. (2009). Information Technology and Its Application in E-learning. 2009 International Conference on Networking and Digital Society, 1, 293-296. https://doi.org/10.1109/ICNDS.2009.79

Billings, D. M. (2002). Conversations in E-learning. Jones \& Bartlett Learning.

Blackburn, G. (2017, January 25). Successful eLearning Implementation: Best Practices. ELearning Industry. https://elearningindustry.com/successful-elearningimplementation-best-practices

Claus, P. (2007). Architecture Solutions for E-Learning Systems. IGI Global.

Crane, B. E. (2016). Online Teaching and Learning: A Practical Guide for Librarians. Rowman \& Littlefield.

Fee, K. (2009). Delivering E-Learning: A Complete Strategy for Design Application and Assessment. Kogan Page Publishers.

Fitria, T. N. (2020). Teaching English through Online Learning System during Covid-19 Pandemic. Pedagogy: Journal of English Language Teaching, 8(2), 138-148. https://doi.org/10.32332/pedagogy.v8i2.2266

Garrison, D. R. (2011). E-Learning in the 21st Century: A Framework for Research and Practice. Taylor \& Francis.

Gluchmanova, M. (2015). Application of e-Learning in Foreign Language Teaching at the Technical University. Procedia - Social and Behavioral Sciences, 174, 3144-3149. https://doi.org/10.1016/j.sbspro.2015.01.1053

Gunasekaran, A., McNeil, R. D., \& Shaul, D. (2002). E-learning: Research and applications. Industrial and Commercial Training, 34(2), 44-53. https://doi.org/10.1108/00197850210417528

Haythornthwaite, C., \& Andrews, R. (2011). E-learning Theory and Practice. SAGE.

Idris, F. elmoula A. alla, \& Osman, Y. (2016). Implementation of E-learning in The University of Gezira Barriers and Opportunities. Educational Sciences and Research, 24-35. https://doi.org/10.22496/esr2016090470

Iskander, M. (2007). Innovations in E-learning, Instruction Technology, Assessment and Engineering Education. Springer Science \& Business Media.

Merriam, S. B. (2009). Qualitative Research: A Guide to Design and Implementation. John Wiley \& Sons.

Merriam, S. B., \& Grenier, R. S. (2019). Qualitative Research in Practice: Examples for Discussion and Analysis. John Wiley \& Sons.

Miles, M. B., \& Huberman, A. M. (1994). Qualitative Data Analysis: An Expanded Sourcebook. SAGE. 
Mohmedsali, N., Kadyamatim, A., \& Madzvamuse, S. (2017). Investigating Factors Influencing the Implementation of e-learning at Rural Based Universities. Information Technology Journal, 16(3), 101-113. https://doi.org/10.3923/itj.2017.101.113

Munkhtsetseg, N., \& Uyanga, S. (2013). Implementation of E-Learning System: Findings and Lessons Learned. Intelligent Information Management, 05(01), 18-24. https://doi.org/10.4236/iim.2013.51003

Nurseha, Y. D., \& Pradany, L. N. (2014). Survei Aplikasi E-learning untuk Mendukung Proses Belajar Mengajar pada Institusi Pendidikan Menggunakan Standar Kualitas ISO/IEC 9126. Jurnal ULTIMA InfoSys, 5(2), 106-111. https://doi.org/10.31937/si.v5i2.272

Rubin, A., \& Babbie, E. R. (2009). Essential Research Methods for Social Work. Cengage Learning.

Sarker, M. F. H., Mahmud, R. A., Islam, M. S., \& Islam, M. K. (2019). Use of e-learning at higher educational institutions in Bangladesh: Opportunities and challenges. Journal of Applied Research in Higher Education, 11(2), 210-223. https://doi.org/10.1108/JARHE-06-2018-0099

Silverman, D. (2009). Doing Qualitative Research. SAGE.

Solangi, Z. A., Al Shahrani, F., \& Pandhiani, S. M. (2018). Factors affecting Successful Implementation of eLearning: Study of Colleges and Institutes Sector RCJ Saudi Arabia. International Journal of Emerging Technologies in Learning (IJET), 13(06), 223. https://doi.org/10.3991/ijet.v13i06.8537

Tsai, P.-W., Tsai, P.-S., Ku, P., Istanda, V., \& Gabe, T. (2017). Application of E-Learning in Teaching of English as a Second Language. In J.-S. Pan, V. Snášel, T.-W. Sung, \& X. D. Wang (Eds.), Intelligent Data Analysis and Applications (pp. 163-170). Springer International Publishing. https://doi.org/10.1007/978-3-319-484990_20

Umadevi, K., Maheswari, B., \& Nithya, P. (2014). Design of E-Learning Application through WebMining. International Journal of Innovative Research in Computer and Communication Engineering, 2, 5324-5329.

Yefim, K. (2010). Learning Management System Technologies and Software Solutions for Online Teaching: Tools and Applications: Tools and Applications. IGI Global. 